\title{
Hadis-Hadis Tentang Jual Beli Gharar Dan Bentuknya Pada Masa Kontemporer
}

\section{(Hadiths about Gharar in Buying and Selling and the Forms in the Contemporary Period)}

\author{
Yenni Samri Juliati Nasution, Ardiansyah, Heri Firmansyah \\ Universitas Islam Negeri (UIN) Sumatera Utara, Indonesia \\ yenni.samri@uinsu.ac.id, ardiansyah@uinsu.ac.id, herifirmansyah@uinsu.ac.id
}

DOI: $10.29240 /$ alquds.v5i1.2194

Submitted: 2020-12-13 |Revised: 2021-03-18 |Accepted: 2021-03-25

\begin{abstract}
This article examines various hadith (traditions) which talk about the issue of gharar sale (uncertain sale). The research finds out that there are dozens of hadiths which are then reduced to 5 hadiths considered to be representative and focus of the discussion, both in terms of the matn and sanad. This research is thematic, namely the hadiths related to gharar law with sanad and matn criticism approach to get a clear picture of the authenticity of the hadiths understudied. To get a comprehensive understanding of the issue of gharar sale, this paper also develops the research on the form of gharar sale in the contemporary era with a figh perspective which is also supported by the arguments found in the Quran. The research finds out that the hadiths which talk about the issue of gharar are categorized as sahih (authentic) with various criteria and therefore can be used as evidence (hujjah) in the making of legal decisions based on Islamic law (istinbath).
\end{abstract}

Keywords: Hadith, Buying and Selling, Gharar, Sanad, Tarjih

\begin{abstract}
Abstrak. Artikel ini dibuat dalam rangka mengkaji berbagai hadis yang berbicara tentang persoalan jual beli gharar. Di dalam penelitian yang dilakukan ada puluhan hadis yang ditemukan dan kemudian dikerucutkan menjadi 5 hadis yang dianggap dapat mewakili dan fokus pada pembahasan yang ingin diteliti, baik dari sisi matan dan sanadnya. Jenis Penelitian dalam tulisan ini adalah tematik yaitu hadis-hadis yang berkaitan dengan hukum gharar dengan pendekatan pengkajian kritik sanad dan matan. Hal ini guna untuk mendapatkan gambaran yang jelas tentang derajat shahih tidaknya hadis yang diteliti. Guna mendapatkan pemahaman yang komprehensif tentang persoalan jual beli gharar, tulisan ini juga mengembangkan penelitiannya pada bentuk jual beli gharar pada masa kontemporer dengan perspektif fikih yang juga didukung dengan landasan dalil-dalil yang terdapat di dalam Alquran. Pada penelitian ini ditemukan bahwa hadis Rasulullah saw yang berbicara tentang persoalan gharar masuk dalam derajat shahih dengan berbagai kriterianya dan karena itu dapat dijadikan sebagai hujjah di dalam pengistibat $\}$ an hukum Islam.
\end{abstract}


Keyword: Hadis, Jual Beli, Gharar, Sanad, Tarjih

\section{Pendahuluan}

Jual beli adalah sebuah transaksi yang dihalalkan oleh Allah swt, sebagaimana yang tertuang di dalam surah Albaqarah ayat 275 bahwa "Allah menghalalkan jual beli dan mengharamkan riba". Namun, ada beberapa jual beli yang diharamkan, salah satunya adalah jual beli yang mengandung unsur gharar. Tulisan ini akan mengkaji transaksi yang mengandung unsur gharar menurut hadis Rasulullah saw dan diterapkan pada beberapa transaksi kontemporer pada masa kini. Karena bisa jadi transaksi yang terjadi pada masa Rasulullah saw secara bentuk tidak ada lagi pada masa kini, namun karakteristik ke-ghararannya terwujud pada bentuk transaksi yang lain.

Artikel ini mengkaji tentang beberapa hadis-hadis Rasulullah yang berbicara permasalahan hukum yang berkaitan tentang persoalan gharar. Beberapa tulisan terkait yang berhasil penulis himpun mengenai persoalan hadis tentang jual beli gharar ini adalah tulisan Nadratuzzaman Hosen pada jurnal tahun 2009 dengan judul "Analisis Bentuk Gharar Dalam Transaksi Ekonomi" dia membahas tentang kondisi ekonomi yang ditopang dengan lembaga keuangan konvensional banyak mengandung unsur gharar yang jelas telah dilarang dalam syariat islam. ${ }^{1}$ Kajiannya tidak ada membahas mengenai hadis tentang gharar, namun lebih kepada kajian fikih. Tulisan yang hampir mirip terbaru adalah tulisan Muh. Fudhail Rahman tahun 2019 yang berjudul, "Hakekat dan Batasan-Batasan Gharar dalam Transaksi Maliyah". Dia membahas tentang empat konsep batasan gharar tanpa ada menyinggung pembahasan mengenai hadis yang berkaitan dengan persoalan jual beli gharar. Kajiannya lebih fokus kepada pembahasan fiqh. ${ }^{2}$ Tulisan yang ada menyinggung tentang hadis gharar adalah dengan judul "Larangan Jual Beli Gharar dalam Musnad Abmad bin Hanbal” yang ditulis oleh Purbayu Budi Santosa dan Aris Anwaril Muttaqin memberikan kesimpulan bahwa hadis yang terdapat pada musnad Imam Ahmad tentang larangan jual beli gharar bersanad shahih dan dapat dijadikan landasan hukum. ${ }^{3}$

Dari pemaparan tulisan-tulisan yang terkait di atas tidak ada yang mirip dengan kajian dalam penelitian tulisan ini sehingga diharapkan akan menambah khazanah keilmuan khususnya yang berkaitan dengan hadis-hadis jual beli gharar dan bentuknya pada masa modern saat ini. Kajian ini dimaksudkan untuk

\footnotetext{
${ }^{1}$ Nadratuzzaman Hosen, "Analisis Bentuk Gharar Dalam Transaksi Ekonomi” Jurnal UIN Syarif Hidayatullah (Al-Iqtishad, Jakarta: 2009), 64.

2 Muh. Fudhail Rahman, "Hakekat dan Batasan-Batasan Gharar dalam Transaksi Maliyab" Jurnal UIN Syarif Hidayatullah (Salam, Jakarta: 2018), 275.

${ }^{3}$ Purbayu Budi Santosa dan Aris Anwaril Muttaqin, "Larangan Jual Beli Gharar dalam Musnad Ahmad bin Hanbal” Jurnal Universitas Diponegoro (Equilibrium, Semarang: 2015), 172
} 
menguatkan dan memperjelas dalil-dalil yang bersumber dari hadis Rasulullah saw tentang pelarangan praktek gharar yaitu satu macam bentuk jual beli yang terlarang di dalam ajaran Islam. Hadis-hadis tersebut berusaha untuk dikumpulkan, lalu dikarenakan keterbatasan halaman maka dipilih dan dikelompokkan beberapa saja yang dianggap mewakili dari keseluruhan hadis, baik dari sisi matan maupun sanadnya.

Hadis-hadis yang dipilih tersebut akan ditarjih dan dikritik sanad dan matannya, untuk mendapatkan gambaran yang jelas tentang derajat dan kedudukan hadis tersebut apakah sahịh atau dha if sehingga akan dapat diterima atau ditolak sebagai dalil dan hujjah dalam menetapkan hukum tentang persoalan gharar. Penelitian ini menggunakan metodologi kritik sanad, seperti yang ada pada tulisan Muhammad Amar Adly, Hadis-Hadis tentang Riba dan Implementasinya dalam Sistem Perbankan, ${ }^{4}$ namun tentu saja berbeda tema dan hadisnya serta hasil penelitiannya pun berbeda.

Tulisan ini juga mengkaji tentang berbagai problematika kontemporer maupun klasik yang berkaitan dengan persoalan jual beli yang mengandung unsur gharar, sehingga akan memperoleh pemahaman yang utuh terhadap persoalan yang dibahas baik pada masa klasik maupun kontemporer.

\section{Hadis Tentang Gharar}

\section{Teks dan Takhrij Hadis}

Gharar secara ringkas dipahami sebagai jual beli yang ada unsur penipuan sehingga merugikan salah satu pihak, utamanya si pembeli. Dalam upaya mentakhri $>j$ hadis dan mengetahui teks beberapa hadis tentang gharar di dalam beberapa kitab hadis, penulis mencarinya dengan kata غرر dalam aplikasi pencarian hadis yang diakses di website https://gethadith.web.app/ dan ditemukan 29 Hadis. Penulis merangkumnya dalam lima Hadis yang memiliki kemiripan matan yang tersebar dari beberapa kitab Hadis. Hadis-hadis tersebut adalah sebagai berikut:

a. Hadis Riwayat Imam Muslim Nomor Hadis $2783^{5}$

${ }^{4}$ Muhammad Amar Adly dan Heri Firmansyah, "Hadis-Hadis tentang Riba dan Implementasinya dalam Sistem Perbankan”, Al Quds, Jurnal Studi Alquran dan Hadis, Volume 4, Nomor 2, 2020, 339.

${ }^{5}$ Imam Muslim dalam Shahihnya, Kitab Al-Buyu', Bab Tahrim Bai' Habalil Habalah, hadits no 2783 . 


$$
\begin{aligned}
& \text { صحيح مسلم rVA } \\
& \text { سعيد وأبو أسامة عن عبيد الله و حدثني زهير بن حرب واللفظ له حدثنا يهيى بن سعيد عن } \\
& \text { عبيد الله حدثني أبو الزناد عن الأعرج عن أبي هريرة قال فهى رسول الله صلى الله عليه وسلم } \\
& \text { عن بيع الحصاة وعن بيع الغرر }
\end{aligned}
$$

Shabih Muslim 2783: Dan telah menceritakan kepada kami Abu Bakar bin Abi Syaibah telah menceritakan kepada kami Abdullah bin Idris dan Yabya bin Sa'id serta Abu Usamah dari Ubaidillah. Dan diriwayatkan dari jalur lain, telah menceritakan kepadaku Zuhair bin Harb sedangkan lafazh darinya, telab menceritakan kepada kami Yabya bin Sa'id dari 'Ubaidillah telah menceritakan kepadaku Abu Az Zinad dari Al A'raj dari Abu Hurairah dia berkata: Rasulullah shallallahu 'alaibi wa sallam melarang jual beli dengan cara hashah (yaitu: jual beli dengan melempar kerikil) dan cara lain yang mengandung unsur penipuan.

b. Hadis Riwawat Imam Tirmidzi nomor Hadis $1151^{6}$

$$
\begin{aligned}
& \text { سنن الترمذي 101 } 1 \text { : : حدثنا أبو كريب أنبأنا أبو أسامة عن عبيد الله بن عمر عن أبي الزناد } \\
& \text { عن الأعرج عن أبي هريرة قال فهى رسول الله صلى الله عليه وسلم عن بيع الغرر وبيع الحصاة } \\
& \text { قال وفي الباب عن ابن عمر وابن عباس وأبي سعيد وأنس قال أبو عيسى حديث أبي هريرة } \\
& \text { حديث حسن صحيح والعمل على هذا الحمديث عند أهل العلم كرهوا بيع الغرر قال الشافعي } \\
& \text { ومن بيوع الغرر بيع السمك في الماء وبيع العبد الآبق وبيع الطير في السماء ونحو ذلك من البيوع } \\
& \text { ومعنى بيع الحصاة أن يقول البائع للمشتري إذا نبذت إليك بالحصاة فقد وجب البيع فيما بيني } \\
& \text { وبينك وهذا شبيه ببيع المنابذة وكان هذا من بيوع أهل الجاهلية }
\end{aligned}
$$

Sunan Tirmidri 1151: Telah menceritakan kepada kami Abu Kuraib telah memberitakan kepada kami Abu Usamah dari Ubaidullab bin Umar dari Abu Az Zinad dari Al A'raj dari Abu Hurairah ia berkata: Rasulullah shallallabu 'alaibi wa sallam melarang jual beli yang mengandung unsur penipuan dan jual beli menggunakan kerikil. Ia mengatakan: Dalam hal I ni ada hadits serupa dari Ibnu Umar, Ibnu Abbas, Abu Sa'id dan Anas. Abu Isa berkata: Hadits Abu Hurairah adalah hadits hasan shahih dan menjadi pedoman amal menurut para ulama, mereka memakrubkan jual beli yang mengandung unsur penipuan. Asy Syafi'i berkata: Termasuk, jual beli yang mengandung unsur penipuan adalab jual beli ikan di air, jual beli seorang budak yang melarikan diri, jual beli burung di langit dan jual beli lain

${ }^{6}$ Imam Tirmidzi dalam Jami'nya, Kitab Al-Buyu' Bab Ma Ja'a Fi Bai'I ba'I Al-Garar, hadits no 1151 , 
yang semacam itu. Maksud jual beli menggunakan kerikil adalah seorang penjual mengatakan kepada pembeli:Jika aku membuang kerikil ini kepadamu, maka wajib terlaksana akad jual beli yang terjadi antara aku dan kamu. Hal ini serupa dengan jual beli munabadzah yang termasuk salah satu dari jual beli orang-orang jahiliyah.

c. Hadis Riwayat Abu Daud nomor Hadis $2932^{7}$

$$
\begin{aligned}
& \text { سنن أبي داوود r rq r : حدثنا أبو بكر وعثمان ابنا أبي شيبة قالا حدثنا ابن إدريس عن عبيد } \\
& \text { الله عن أبي الزناد عن الأعرج عن أبي هريرة أن النبي صلى الله عليه وسلم هیى عن بيع الغرر زاد } \\
& \text { عثمان والحصاة }
\end{aligned}
$$

Sunan Abu Daud 2932: Telah menceritakan kepada kami Abu Bakr dan Utsman dua anak Abu Syaibah, mereka berkata: telah menceritakan kepada kami Ibnu Idris dari 'Ubaidullah dari Abu Az Zinad dari Al A'raj dari Abu Hurairah babwa Nabi shallallahu 'alaibi wa sallam melarang menjual secara gharar (transaksi jual beli yang mengandung unsur ketidakjelasan, penipuan, pertaruban, dan hal-hal yang merugikan). Sedang Utsman menambabkan: Dan has\}ah (transaksi jual beli yang dilakukan oleh dua orang tetapi barangnya belum jelas, kemudian untuk menentukannya salah satu dari mereka melempar hashah (kerikil), maka barang yang terkena kerikil itulah yang dijual).

d. Hadis Riwayat Imam An-Nasa'i nomor Hadis $4442^{8}$

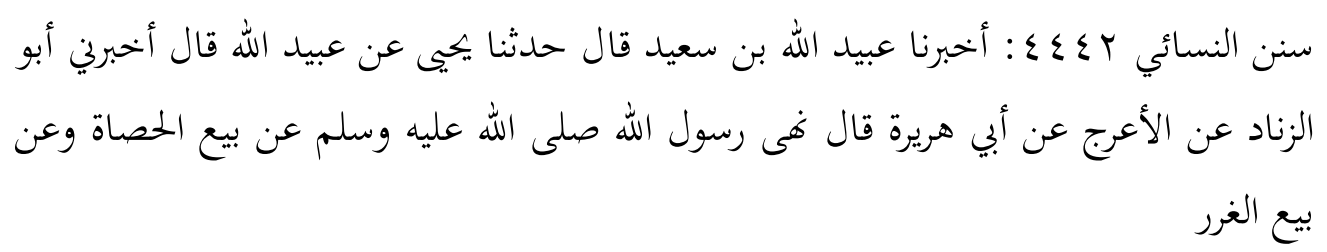

Sunan Nasa'i 4442: 'Ubaidillah bin Sa'id telah memberikan kabar kepada kami, dengan perkataannya:babwa telah bercerita terhadap kami Yahya dari 'Ubaidullah, ia berkata: bahwa Abu Az Zinad memberikan kabar kepadaku yang berasal dari kabarAl A'raj dari Abu Hurairah, ia berkata: Rasulullah saw., melarang dari menjual dengan cara has\} ah dan jual beli gharar (tidak.jelas).

e. Hadis Riwayat Ibnu Majah nomor Hadis $2185^{9}$

2932.

${ }^{7}$ Imam Abu Daud dalam Sunannya, Kitab Al-Buyu', Bab Fi Bai' al-Gharar, hadits no

${ }^{8}$ Imam Nasa'i dalam Sunannya, Kitab Al-Buyu', Bab Bai' Hashah, hadits no 4442.

${ }^{9}$ Imam Ibnu Majah dalam Sunannya, Kitab At-Tijarat, Bab An-Nabyi An Syira' ma fi buthunil An'am wa Dhuru'iba, Hadis no 2185 


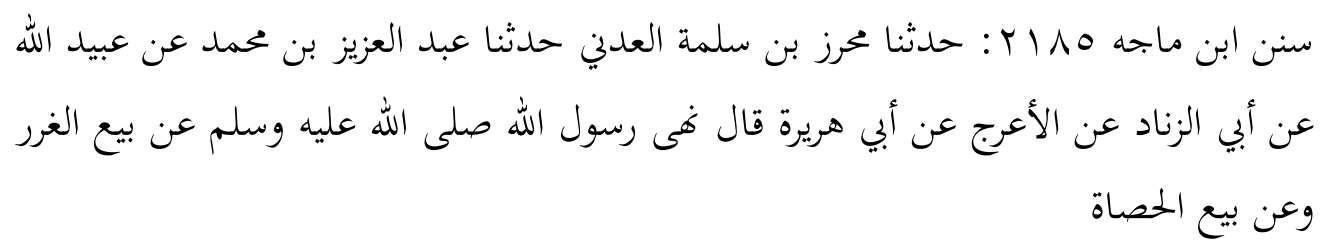

Sunan Ibnu Majah 2185: Telab menceritakan kepada kami Mubriz bin Salamah Al'Adani berkata: telah menceritakan kepada kami Abdul Aziz. bin Mubammad dari Ubaidullah dari Abu Az Zinad dari Al A'raj dari Abu Hurairah ia berkata: "Rasulullah shallallabu 'alaibi wa sallam melarang jual beli gharar (menimbulkan kerugian bagi orang lain) dan jual beli bas\}ah."

\section{Tela'ah Sanad Hadis tentang Gharar}

Untuk memudahkan dan mempersingkat penela'ahan, Urutan sanad yang menampilkan Rijalul hadis yang dibahas dalam makalah ini hanya berasal dari dua sanad saja yaitu hadis yang termuat pada kitab Hadis Imam Muslim dan Imam AtTirmidzi. Adapun penjelasannya adalah sebagai berikut:

a. Sanad Dalam Hadis Riwayat Muslim nomor Hadis 2783

Dalam hadis Muslim nomor Hadis 2783 yang membahas Hadis tentang gharar ini, ada 4 jalur variasi sanad seperti yang diungkapkan dan dipahami dari sanad Hadis di atas. Perbedaan Jalurnya hanya terjadi pada tingkat yang kelima dan keenam, sedangkan jalur dari satu sampai keempat tetap sama. Jalur sanad yang sama adalah Abdurrahman bin Sakhr (Abu Hurairah), Abdurrahman bin Hurmus (yang memiliki kunyah Abu daud dan terkenal denan al-A'raj), Abdullah bin Zakwan Abu az-Zanad dan Ubaidillah bin Umar bin Hafsh bin Ashim bin Umar bin al-Khattab. Dalam makalah ini hanya disebutkan 2 variasi jalur sanad yang berbeda: 

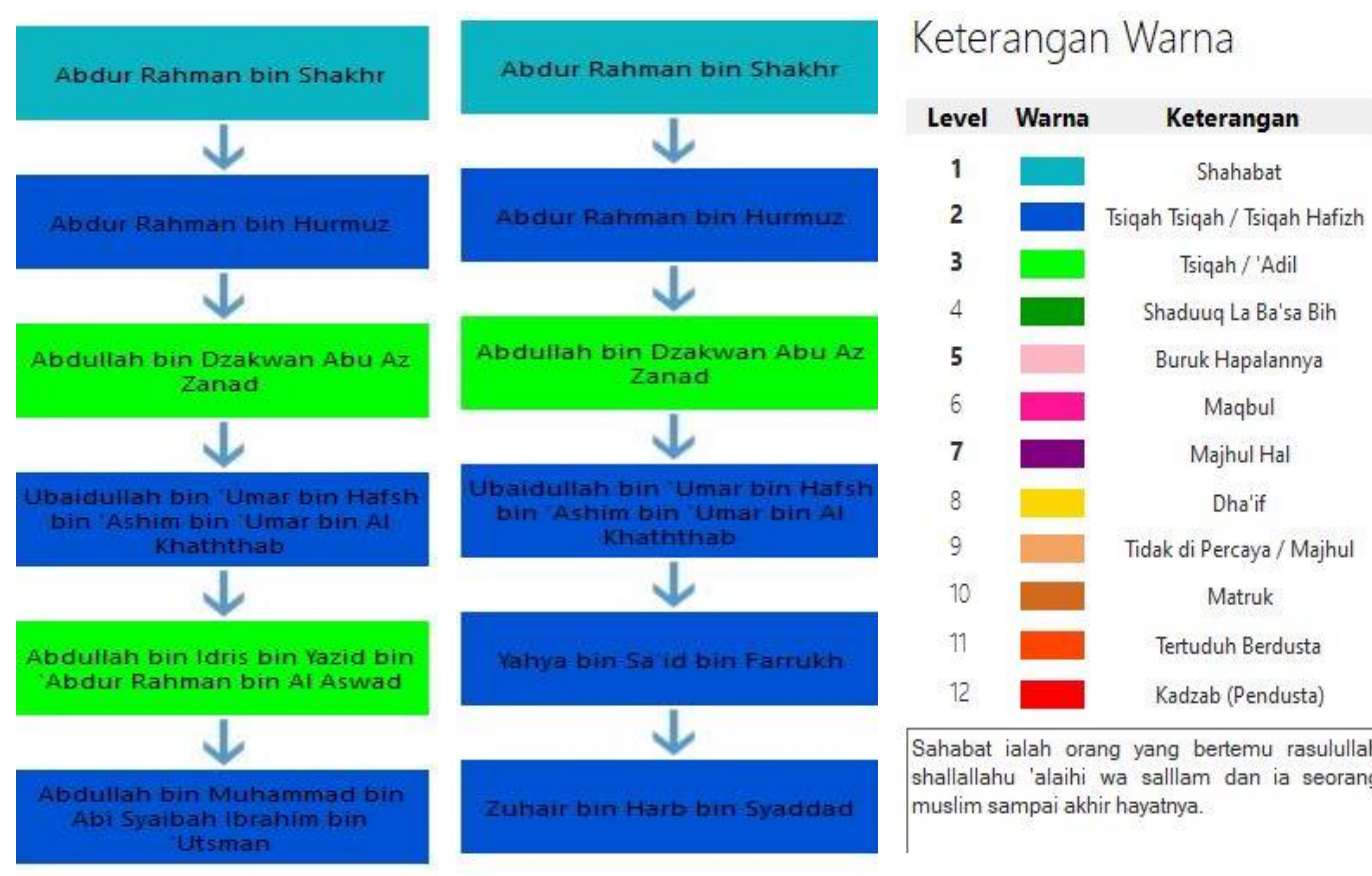

Sahabat ialah orang yang bertemu rasulullal shallallahu 'alaihi wa sallam dan ia seoran! muslim sampai akhir hayatnya.

Gambar 1 : Jalur sanad 1, jalur sanad 2 Hadis Riwayat Muslim, keterangan warna

Secara umum kedua jalur sanad Hadis riwayat Muslim ini dalam ijma ulama dinilai șahịh, karena terpenuhi persyaratan ittișal as-sanad dan mayoritas ulama menilai para rijāl al-hadisnya dalam derajat siqah. Jalur pertama tentang pribadi singkat rijalul hadis dari bagan di atas adalah sebagai berikut:

1. Abdur Rahman bin Shakhr.

Nama lengkapnya adalah Abu Hurairah al-Dawsiy al-Yamaniy Abdur Rahman bin Shakhr. Beliau Lebih terkenal dengan Kunyahnya yaitu Abu Hurairah dengan nasab Ad Dawsiy Al Yamaniy. Dia merupakan kalangan sahabat yang senantiasa hidup di Madinah hingga wafatnya pada Tahun $57 \mathrm{H}$, dalam usia 78 Tahun. ${ }^{10}$

Tentang beliau, Ibnu Hajar berpendapat bahwa Abu Hurairah adalah termasuk sahabat yang mulia dan hafiz dari kalangan sahabat. ${ }^{11}$ Jumlah Hadis yang diriwayatkannya adalah sebagai berikut, Bukhari : 1039, Muslim : 1009,

\footnotetext{
${ }^{10}$ Ibnu Hajar, Tahżīb al-Tahżib, Jild 10, 294.

${ }^{11}$ Ibnu Hajar al-`Asqalāniy, Taqrīb at-Tahżīb (Beirut: Da>r al-Fikr, 1995), jild 2, 774.
} 
Tirmidzi : 598, Abu Daud : 544, Nasa'i : 644, Ibnu Majah : 631, Darimi : 265, Ahmad : 3842, Malik : 171.

2. Abdur Rahman bin Hurmuz.

Kunyah beliau adalah Abu Daud dengan Laqob 'Al A'raj'. Dia memiliki Nasab : Al Madaniy ${ }^{12}$ dan berada pada kelompok Tabi'in dari kalangan pertengahan. Keseharian kehidupannya berada di Kota Madinah dan meninggal dunia di Iskandariyah, Tahun $117 \mathrm{H}$. Jumlah Hadis yang diriwayatkan adalah sebagai berikut:Bukhari : 194, Muslim : 140, Tirmidzi : 40, Abu Daud : 53, Nasa'i : 86, Ibnu Majah : 47, Darimi : 26, Ahmad : 306 dan Malik : 68.

Komentar ulama tentang beliau: 1) Ibnu Hajar al 'Asqalani: siqah șabät, 2) Ibnu Sa'd: siqah, 3) Ibnu Kharasy: siqah, 4) Abu Zur'ah: siqah, 5) Ibnul Madini: siqah, 6) Ibnu Hibban: disebutkan dalam As-śiqah, 7) Al-'Ajli: siqah

3. Abdullah bin Dzakwan Abu Az Zanad

Nama lengkapnya adalah Abdullah bin Zakwan al-Qarsyiyyi Abu Abdur Rahman al-Madaniy. ${ }^{13}$ Kunyah beliau adalah Abu 'Abdur Rahman dengan Laqob: Abu Az Zannad. Dia memiliki Nasab Al Qurasyiy dan berasal kalangan Tabi'in kalangan biasa. Sehari-hari hidup di Madinah hingga wafatnya pada Tahun $130 \mathrm{H}$. Jumlah Hadits yang diriwayatkan beliau adalah Bukhari : 156, Muslim : 112, Tirmidzi : 37, Abu Daud : 47, Nasa'i : 61, Ibnu Majah : 31, Darimi : 23, Ahmad : 273, Malik : 65.

Komentar ulama tentang beliau: 1) Ahmad bin Hambal: siqah, 2) Ibnu Hajar Al Atsqalani: siquh, fäqīh, 3) Ibnu Hibban: disebutkan dalam 'aś-siqah, 4) An Nasā'i: śiqah, 5) Ath Ṭabrānì: śiqah, 6) Al 'Ajli: śiqah, 7) Adz Dzahabi: śiqah, sabāt

4. Ubaidullah bin 'Umar bin Hafsh bin 'Ashim bin 'Umar bin Al Khaththab

Kunyah beliau adalah Abu 'Utsman dengan nasab Al 'Adawiy Al 'Umariy. Dia berasal dari Tabi'in kalangan biasa. Dia lama hidup di Madinah hingga wafatnya pada Tahun $147 \mathrm{H}$. salah satu dari 7 ulama fikih terbesar yang ada di Madinah. ${ }^{14}$ Jumlah Hadits yang diriwayatkannya adalah sebagai berikut: Bukhari : 163, Muslim : 180, Tirmidzi : 64, Abu Daud : 79, Nasa'i : 99, Ibnu Majah : 98, Darimi : 50 dan Ahmad : 357.

Komentar ulama tentang beliau: 1) An Nasa'i dan Ibnu Hajar: siqahșabāt, 2) Abu Zur'ah, Adz Dzahabi, Abu Hatim, dan Yahya bin Ma'in: śiqah

\footnotetext{
${ }^{12}$ Ibid., Jild. 6, 290.

${ }^{13}$ Ibid., Jild. 5, 203.

${ }^{14}$ Ibid., Jild. 7, 38.
} 


\section{Abdullah bin Idris Abu Muhammad}

Nama lengkap beliau adalah Abdullah bin Idris bin Yazid bin Abd ArRahman bin al-Aswadi al-Audiy az-Za'afiriy Abu Muhammad al-Kufiy. Kunyah beliau adalah Abu Muhammad dengan Nasab : Al Awdiy Az Zi'afiriy. ${ }^{15}$ Dia berada pada derajat kelompok Tabi'ut Tabi'in dari golongan pertengahan. Keseharian hidup di wilayah Kufah hingga wafatnya pada Tahun 192 H. Jumlah Hadis yang diriwayatkannya adalah Bukhari : 10, Muslim : 61, Tirmidzi : 20, Abu Daud : 33, Nasa'i : 34, Ibnu Majah : 42, Darimi : 21 dan Ahmad : 49.

Komentar ulama tentang beliau: 1) Ibnu Hajar al-'Asqalāni: siqah, fāqìh, 2) Abu Hatim: śiqah, 3) Adz Dzahabi: seorang tokoh, 4) An Nasā'i: siqah-ṣabāt, 5) Al 'Ajli: siqah-șabāt, 6) Ibnu Hibban: disebutkan dalam aś-siqāt

6. Abdullah bin Muhammad bin Abi Syaibah Ibrahim bin 'Utsman

Nama lengkap beliau adalah Abdullah bin Muhammad bin Abi Syaibah Ibrahim bin Usman bin Khawasity al-A'basiy. Kunyah beliau adalah Abu Bakar dengan Nasab Al 'Abasiy. ${ }^{16}$ Dia berada pada derajat Tabi'ul Atba' dai kelompok golangan tua yang hidup di Kufah dan wafat Tahun $235 \mathrm{H}$. Jumlah Hadis yang diriwayatkannya adalah Bukhari : 19, Muslim : 1301, Abu Daud : 60, Nasa'i : 2, Ibnu Majah : 1098, Darimi : 33 dan Ahmad : 123.

Komentar ulama tentang beliau: 1) Ahmad bin Hambal: Șadūq, 2) Abu Hatim: siqah

Jalur kedua dari keterangan rijalul Hadis yang terdapat pada sanad Hadis riwayat Muslim di atas dari nomor 5 sampai 6 (karena nomor 1 sampai 4 sama) adalah sebagai berikut:

5. Yahya bin Sa'id bin Farrukh

Nama lengkapnya adalah Yahya bin Sa'id bin Farukh al-Qathan alTamimiy Abu Sa'id al-Bashariy al-Ahwal al-Hafiz. Kunyah beliau adalah Abu Sa'id dengan Laqob: Al Ahwal al-Hafiz dan nasab Al Qaththan At Tamimiy. ${ }^{17}$ Dia berasal dari Kalangan Tabi'ut Tabi'in kalangan biasa dan hidup di Bashrah hingga wafatnya pada tanggal $198 \mathrm{H}$. Jumlah Hadits yang diriwayatkan beliau adalah Bukhari : 298, Muslim : 214, Tirmidzi : 108, Abu Daud : 231, Nasa'i : 341, Ibnu Majah : 79, Darimi : 33 dan Ahmad : 1339.

${ }^{15}$ Ibid., Jild. 5, 144.

${ }^{16}$ Ibid., Jild 6, 2.

${ }^{17}$ Ibid., jild. 11216. 
Komentar ulama tentang beliau: 1) Ibnu Hajar al 'Asqalani: śiqah mutqin, 2) An Nasa'i: śiqah-sabat, 3) Adz Dzahabi: hafiz kabir, 4) Abu Zur'ah: siqah hafiz, 5) Al 'Ajli: siqah, 6) Abu Hatim : śiqah, hafiz

6. Zuhair bin Harb bin Syaddad

Nama lengkapnya adalah Zuhair bin Harb bin Syadda al-Harsyi Abu Khaisamah an-Nasai. Kunyah beliau adalah Abu Khaitsamah dan nasab Al Harasyi An Nasa'iy. Imam Muslim meriwayatkan darinya 1281 Hadis.

Dia berada pada derajat golongan Tabi'ul Atba' dari kelompok tua, Lahir pada Tahun $160 \mathrm{H}$, hidup di Baghdad hingga wafatnya, Tahun $234 \mathrm{H} .{ }^{18} \mathrm{Jumlah}$ Hadis yang diriwayatkannya adalah Bukhari : 12, Muslim : 749, Abu Daud : 43, Nasa'i : 1, Ibnu Majah : 2, Darimi : 1 dan Ahmad : 35.

Komentar ulama tentang beliau: 1) Ibnu Hajar al 'Asqalani: siqah șabät, 2) Yahya bin Ma'in: śiqah, 3) Adz Dzahabi: alhafiz, 4) An Nasa'i : śiqah-ma'mūn,

5) Ibnu Hibban: disebutkan dalam aṣ-siqqāt, 6) Abu Hatim: Șiqah-siabāt

b. Sanad Dalam Hadis Riwayat Imam At-Tirmidzi nomor hadis 1151

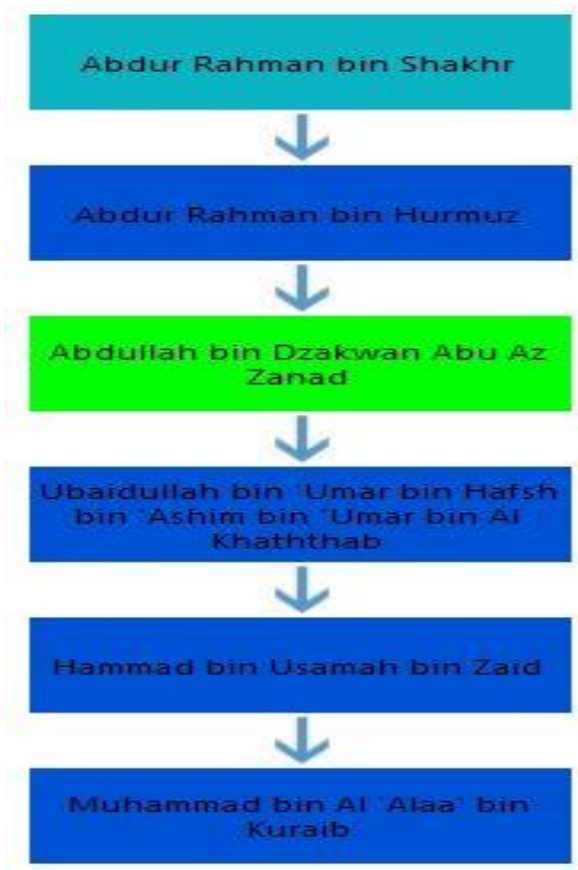

Gambar 2 : Jalur Sanad Hadis Riwayat Imam At-Tirmidzi

${ }^{18}$ Ibid., Jild 3, 342-343. 
Jika dilihat pada gambar 2, yang menarik adalah bahwa jalur sanad hadis yang diriwayatkan oleh Imam At-Tirmidzi sama dengan jalur sanad hadis yang diriwayatkan oleh Imam Muslim dengan 4 variasi jalur sanadnya, dalam tingkatan pertama sampai dengan ke empat. Bisa dikatakan mulai tingkatan periode sahabat, tabi'in, tabi'tabiin dan murid tabi' at-Tabi'in. perbedaannya pada tingkatan yang kelima dan keenam, seperti juga variasi jalur sanad yang diriwayatkan oleh Hadis Imam Muslim.

Hadis ini dinilai sahih oleh Muhammad Nasiruddin al-Albani dan Abu Thahir Zubai Ali Zai, karena jalur sanad dalam hadis ini memenuhi kriteria keshahihan suatu hadis dengan kriterianya di antaranya ittishal as-sanad dan para Rijäl al-Hadišnya siqah. Adapun dUrutan penilaian rijalul Hadis dalam sanad tersebut adalah:

\section{Abdur Rahman bin Shakhr}

Beliau Lebih terkenal dengan Kunyahnya yaitu Abu Hurairah dengan nasab Ad Dawsiy Al Yamaniy. Dia merupakan kalangan sahabat yang senantiasa hidup di Madinah hingga wafatnya pada Tahun 57 H. ${ }^{19}$ Jumlah Hadis yang diriwayatkannya adalah sebagai berikut, Bukhari : 1039, Muslim : 1009, Tirmidzi : 598, Abu Daud : 544, Nasa'i : 644, Ibnu Majah : 631, Darimi : 265, Ahmad : 3842, Malik : 171 .

\section{Abdur Rahman bin Hurmuz.}

Kunyah beliau adalah Abu Daud dengan Laqob 'Al A'raj'. Dia memiliki Nasab Al Madaniy dan berada pada kelompok Tabi'in dari kalangan pertengahan. Keseharian kehidupannya berada di Kota Madinah dan meninggal dunia di Iskandariyah tahun $117 \mathrm{H}$. Jumlah Hadis yang diriwayatkan adalah sebagai berikut: Bukhari : 194, Muslim : 140, At-Tirmidzi : 40, Abu Daud : 53, Nasa'i : 86, Ibnu Majah : 47, Darimi : 26, Ahmad : 306 dan Malik : 68.

Komentar ulama: 1) Ibnu Hajar al 'Asqalani: siqahsabät, 2) Ibnu Sa'd: siqah, 3) Ibnu Kharasy: siqah, 4) Abu Zur'ah: siqah, 5) Ibnul Madini: siqah, 6) Ibnu Hibban: disebutkan dalam As-siqah, 7) Al-'Ajli: siqah

3. Abdullah bin Dzakwan Abu Az Zanad

Nama lengkapnya adalah Abdullah bin Zakwan al-Qarsyiyyi Abu Abdur Rahman al-Madaniy. Kunyah beliau adalah Abu 'Abdur Rahman dengan laqob Abu Az Zannad. ${ }^{20}$ Dia memiliki Nasab Al Qurasyiy dan berasal kalangan Tabi'in

${ }^{19}$ Ibid., Jild 10, 294.

${ }^{20}$ Ibid., jild. 5, 203. 
kalangan biasa. Sehari-hari hidup di Madinah hingga wafatnya pada Tahun $130 \mathrm{H}$. Jumlah Hadits yang diriwayatkan beliau adalah Bukhari : 156, Muslim : 112, Tirmidzi : 37, Abu Daud : 47, Nasa'i : 61, Ibnu Majah : 31, Darimi : 23, Ahmad : 273, Malik : 65.

Komentar ulama: 1) Ahmad bin Hambal: siqah, 2) Ibnu Hajar Al Atsqalani: siqah, fäqīh, 3) Ibnu Hibban: disebutkan dalam 'ás-siqah, 4) An Nasā̄i: siqah, 5) Ath Tạrānì: śiqah, 6) Al 'Ajli: śiqah, 7) Adz Dzahabi: siqahsabät.

4. Ubaidullah bin 'Umar bin Hafsh bin 'Ashim bin 'Umar bin Al Khaththab

Kunyah beliau adalah Abu 'Utsman dengan nasab Al 'Adawiy Al 'Umariy. ${ }^{21}$ Dia berasal dari Kalangan Tabi'in kalangan biasa. Dia lama hidup di Madinah hingga wafatnya pada Tahun $147 \mathrm{H}$. Jumlah Hadits yang diriwayatkannya adalah sebagai berikut: Bukhari : 163, Muslim : 180, At-Tirmidzi : 64, Abu Daud : 79, Nasa'i : 99, Ibnu Majah : 98, Darimi : 50 dan Ahmad : 357.

Komentar ulama: 1) An Nasa'i: siqqahsabāt, 2) Ibnu Hajar: siqah-ṣabāt, 3) Abu Zur'ah: siqah, 4) Adz Dzahabi: śiqah, 5) Abu Hatim: śiqah, 6) Yahya bin Ma'in: siqah

5. Hammad bin Usamah bin Zaid

Nama lengkapnya adalah Hammad bin Usamah bin Zaid al-Qarasyi. Kunyah beliau adalah Abu Usamah. ${ }^{22}$ Dia berada pada derajat Tabi'ut Tabi'in dari kalangan biasa. Hidup kesehariannya berada di daerah Kufah hingga meninggalnya pada Tahun $201 \mathrm{H}$. Jumlah Hadis yang diriwayatannya adalah Bukhari : 180, Muslim : 246, At-Tirmidzi : 44, Abu Daud : 54, Nasa'i : 30, Ibnu Majah : 100, Darimi : 29 dan Ahmad : 93.

Komentar ulama: 1) Adz Dzahabi : Hujjah, 2) Ibnu Hibban : disebutkan dalam aṣ-siqah, 3) Yahya bin Ma'in : siqqah, 4) Al-'Ajli : śiqah

6. Muhammad bin Al 'Alaa' bin Kuraib

Kunyah beliau adalah Abu Kuraib dengan Nasab Al-Hamdaniy. Dia berada pada derajat Tabi'ul Atba' dari golongan tua yang hidup di daerah Kufah dan meninggal pada Tahun $248 \mathrm{H}$. Jumlah Hadis yang diriwayatkannya adalah Bukhari: 54, Muslim : 488, Tirmidzi : 176, Abu Daud : 94, Nasa'i : 34, Ibnu Majah : 105, Darimi : 16, Ahmad : 4.

${ }^{21}$ Ibid., jild. 7, 38.

${ }^{22}$ Ibid., Jild. 3, 3-4. 
Komentar ulama: 1) Ibnu Hajar al 'Asqalani: șiqah-hạfiz, 2) Adz Dzahabi: Hafiz, 3) Abu Hatim: Șadūq, 4) Ibnu Hibbān : disebutkan dalam aśśsiqah, 5) An-Nasā'i: la ba'sa bihi

\section{Telaah Matan Hadis Tentang Gharar}

Kelima Hadis yang ditampilkan di atas masing-masing diriwayatkan oleh Imam Muslim, Imam Nasai, Imam At-Tirmidzi, Imam Abu Daud, dan Imam Ibnu Majah. Dari sisi matannya, nampak subtansinya hampir sama dengan redaksi yang agak sedikit berbeda. Mayoritas matannya adalah "bahwa Rasulullah saw. melarang untuk jual beli secara gharar dan b\}as\}ab". Menilik pada matan hadis dapat disimpulkan bahwa matan dapat diterima dan berkedudukan shahih karena tidak ada bertentangan dengan Alquran, hadis yang lain atau prinsip-prinsip umum syariat hukum Islam. Matan Hadis semakin memberikan penguatan untuk melakukan jual beli yang amanah dan jujur dan tidak mengandung unsur gharar yaitu semacam spekulasi dan penipuan.

Dari matan hadis diatas dapat disimpulkan bahwa Rasulullah saw melarang untuk melakukan jual beli dengan cara gharar dan $h\} a s\} a h . H\} a s\} a b$ adalah praktek jual beli di jaman jahiliyyah dimana barang yang dijual belum dapat dipastikan, lalu pembeli atau penjual melemparkan batu kerikil (hasah), mana barang yang terkena dari batu yang dilemparkan tersebut, itulah barang yang dimiliki oleh pembeli. Dalam jual beli ini terdapat unsur kerugian dari salah satu pihak, baik penjual atau pembeli, karena harga telah ditentukan duluan sebelum terjadinya pelemparan batu kerikil. Bisa jadi barang yang terkena kerikil jauh lebih murah dari kesepakan harga yang ditentukan kedua belah pihak, sehingga merugikan pembeli. Semacam ada unsur perjudian dan peruntungan dengan praktek jual beli seperti ini karena itu Rasulullah saw melarangnya. Namun, jual beli hasah ini tidak menjadi fokus dalam makalah ini, yang menjadi fokusnya adalah jual beli yang mengandung unsur gharar (manipulasi). Kenapa jual beli gharar disatukan dengan jual beli hasah, menurut Wahbah Zuhaili karena pembelian sistem $b\} a s\} a h$ ini juga mengandung unsur gharar, karena jual beli sistem ini berkembang di jaman jahiliah karena itu disebutkan oleh Rasulullah saw secara khusus. ${ }^{23}$

Jual beli dalam bentuk yang mengandung gharar merupakan situasi dimana terjadi 'ketidakpastian informasi'antara kedua belah pihak yang bertransaksi. Dalam gharar ini kedua belah pihak sama-sama tidak memiliki kepastian mengenai sesuatu yang ditransaksikan. Menurut Adi Warman bahwa Gharar bisa terjadi bila

\footnotetext{
${ }^{23}$ Wahbah Zuhaili, al-Fiqh al-Islami>, 103.
} 
kita mengubah sesuatu yang seharusnya bersifat pasti menjadi tidak pasti. ${ }^{24}$ Gharar muncul disebabkan oleh: 1). karena ketiadaan pengetahuan (jabl:ketidaktahuan), 2). Obyek sekarang tidak ada, 3). Sebab obyek tidak pada kekuasaan penjual. ${ }^{25}$

Dengan demikian konsep gharar dapat dibagi menjadi dua kelompok, pertama, unsur resiko yang mengandung keraguan, probabilitias dan ketidakpastian secara dominan. kedua unsur meragukan yang kaitannya dengan unsur penipuan atau kejahatan oleh salah satu pihak terhadap pihak lainnya.

\section{Dasar hukum gharar dalam Al-Qur'an}

Al-Qur'an dengan tegas telah melarang semua transaksi bisnis yang mengandung unsur kecurangan dalam segala bentuk terhadap pihak lain. Adapun dalil-dalilnya sebagai berikut:

Pertama: Firman Allah surah Al-Baqarah ayat 188:

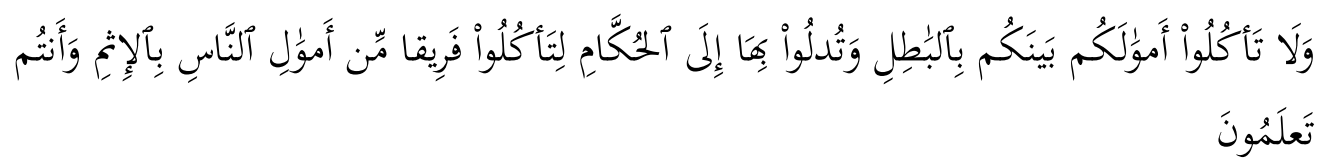

"Dan janganlah sebahagian kamu memakan harta sebahagian yang lain di antara kamu dengan jalan yang batil dan (janganlab) kamu membawa (urusan) barta itu kepada bakim, supaya kamu dapat memakan sebahagian daripada harta benda orang lain itu dengan (jalan berbuat) dosa, padahal kamu mengetahui”.

Kedua: Firman Allah swt surah an-Nisa' ayat 29:

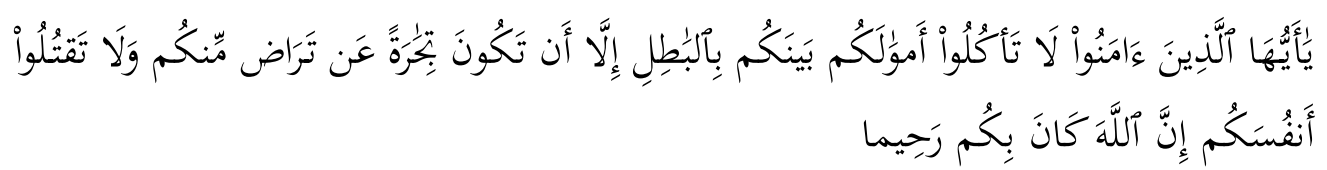

"Hai orang-orang yang beriman, janganlah kamu saling memakan harta sesamamu dengan jalan yang batil, kecuali dengan jalan perniagaan yang berlaku dengan suka sama-suka di antara kamu. Dan janganlah kamu membunub dirimu; sesunggubnya Allah adalah Maha Penyayang kepadamu".

Dari apa yang disampaikan Allah swt di atas yang termuat di dalam kitab suci Al-Qur'an, dapatlah kita mengambil kesimpulan dan pelajaran bahwa Allah SWT melarang jual beli dengan cara batil serta larangan merugikan orang lain dan diri sendiri. Meskipun di dalam kedua ayat yang dituliskan di atas tidak secara

${ }^{24}$ Adiwarman Karim, Bank Islam: Analisis Figh dan Keuangan(Jakarta: Raja Grafido Persada, 2004), h. 31

${ }^{25}$ Ibrahim Warde, Islamic Finance In Th Global Economy, Edinburgh University Press, 2001. 60. 
langsung dan jelas menyebutkan tentang pelarangan jual beli yang mengandung gharar, namun secara umum dapat dipahami bahwa Allah swt melarang untuk memakan harta orang lain dengan cara yang tidak baik dan tidak benar, dengan cara yang batil dan salah. Larangan ini secara umum berarti melarang juga untuk melakukan jual beli dalam bentuk gharar yang mengandung manipulasi dan penipuan karena merugikan orang lain, mendapatkan dan memakan harta dari orang lain dengan cara yang tidak benar atau batil. Jual beli gharar ini akan cenderung mendatangkan permusuhan dan perselisihan karena ketidakpuasan dan merasa tertipu oleh salah satu pihak yang umumnya di alami oleh si pembeli.

\section{Pembahasan Hukum Gharar}

Secara bahasa, gharar berarti risiko, bahaya ${ }^{26}$, mengisap, upaya merusak, imperil. ${ }^{27}$ Dalam kitab Muhadzab, gharar mengandung arti sesuatu yang tersembunyi keadaaannya dan tidak jelas akibatnya. Kata gharar juga terkadang digunakan untuk sesuatu yang mengandung arti penyesatan, penipuan, sesuatu yang membahayakan dan mendatangkan risiko. Dalam interaksi dan transaksi di dunia keuangan, makna gharar dapat mengandung arti suatu 'spekulasi, ketidakpastian dan risiko. ${ }^{28}$

Secara terminologi menurut Wahbah Zuhaili dengan mengutip pendapat Prof az-Zarqa jual beli gharar adalah jual beli barang yang tidak pasti ada wujudnya dan tidak pasti ada batasannya, hal ini disebabkan adanya unsur tipuan dan spekulasi yang menyamai jenis tindakan perjudian. Jenis gharar yang membuat batal transaksi jual beli adalah yang tidak jelas wujud barangnya, dalam artian ada kemungkinan barang ada atau tidak ada. Jadi kesimpulannya jual beli gharar adalah jual beli yang mengandung bahaya dan kerugian bagi salah satu pihak yang terlibat dalam transaksi jual beli tersebut dan bisa mengakibatkan hilangnya harta atau barangnya. ${ }^{29}$ Jual beli gharar terjadi karena ketidakpastian dalam pertukaran. Jika di dalamnya mengandung sebuah tindakan dan transaki yang berbentuk spekulasi, suatu pertukaran atau jual beli tersebut akan menghasilkan ketidakpastian dan akan menimbulkan satu dari tiga kemungkinan: yaitu rugi, untung dan 'impas' yaitu tidak untung dan tidak rugi (impas). Ketidakpastian yang timbul dari aksi spekulasi dalam suatu pertukaran atau jual beli seperti inilah yang dalam ajaran

${ }^{26}$ Atabik, Kamus Al-Ashri(Yogyakarta: Multi Karya Grafika 2008), 1347.

${ }^{27}$ Qal'aji, Mu'jam Lugah al-Fuqaha', Maktabah Syamilah t.th), 137.

${ }^{28}$ Warde Ibrahim,Islamic Finance, terj. Andriyadi Ramli (Yogyakarta: Pustaka Pelajar, 2009), 126.

${ }^{29}$ Wahbah Zuhaili, al-Fiqh al-Islamiy, 101. 
Islam disebut sebagai taghrir (gharar) dan sesuatu dilarang, karena kecenderungannya adalah merugikan salah satu pihak yang bertransaksi. ${ }^{30}$

Para ahli fiqih sepakat bahwa jual beli gharar merupakan jual beli yang tidak sah menurut syara'. Misalnya jual beli mutiara yang masih dalam rumah kerang, binatang yang masih dalam kandungan, ikan yang berada dalam air, burung di udara yang belum ditangkap dan jual beli barang milik orang lain yang belum dimiliki ${ }^{31}$. Jual beli itu tidak sah menurut syara' karena mengandung risiko dan ketidakpastian baik dalam hal jumlah maupun waktu. Dengan kata lain, gharar mengacu pada transaksi yang belum jelas, yaitu transaksi yang dikondisikan pada situasi dan kondisi yang belum pasti.

\section{Bentuk Transaksi Gharat Masa Kini}

Pada era modern ini, pelarangan gharar semakin relevan. hal ini bisa dilihat dari pasar keuangan masa kini yang banyak mengandung unsur memindahkan dan membebankan suatu risiko kepada pihak lain misalnya pasar modal, asuransi konvensional dan berbagai transaksi keuangan lainnya yang mengandung unsur spekulasi seperti perjudian. Sistem transaksi keuangan yang mengandung unsur perjudian. Sistem inilah yang ingin diperbaiki oleh Islam agar proses transaksi tetap membuat dan menguatkan persaudaraan, ukhuwah tetap terjalin dan tidak malah menimbulkan permusuhan bagi yang melalukan transaksi dalam pasar keuangan atau transaksi ekonomi.

Menurut Wahbah Zuhaili, praktik asuransi yang ada saat ini masih banyak yang mengandung unsur gharar. Transaksi asuransi dengan perusahaanperusahaan asuransi termasuk transaksi kompensasi keuangan dan karenanya gharar berpengaruh di dalam sistemnya. Seperti misalnya transaksi asuransi yang berlaku pada kecelakaan-kecelakaan yang terjadi di kemudian hari yang secara pasti tidak diketahui kejadiannya. Dengan demikian, gharar adalah unsur penting dalam asuransi. Karena mengandung unsur gharar, maka asuransi semacam ini termasuk dalam hadis Rasulullah saw jual beli yang dilarang. ${ }^{32}$

Jual beli dengan cara pengkreditan, pada dasarnya menurut mayoritas jumhur ulama halal dan diperbolehkan, namun saat ini ada sistem perkreditan yang berkembang tidak pada koridor yang benar yaitu jual beli dengan cara pengkreditan menggunakan sistem bunga yang naik turun atau fluktuatif sehingga tidak diketahui berapa harga pasti barang yang kita beli. Jika jumlahnya pasti inilah yang diperbolehkan jumhur ulama, namun jika tidak pasti sehingga mungkin mengalami kenaikan dan seperti ada unsur pengelabuan atau penipuan, maka jual

\footnotetext{
${ }^{30}$ Karim Adiwarman A. Bank Islam Analisis Fiqib danKeuangan, Jakarta: RajaGrafindo, 2013: 80).

${ }^{31}$ Wahbah Zuhaili, al-Fiqh al-Islami, 438.

${ }^{32}$ Wahbah Zuhaili, al-Fiqh al-Islami, 108.
} 
beli seperti ini masuk unsur gharar dan termasuk jual beli yang diharamkan. Dalam tuntunan hukum Islam, transaksi jual beli wajib untuk dipastikan antara penjual dan pembeli yang berhubungan dengan harga barang yang ingin dibeli atau dijual, tidak dibenarkan adanya perubahan yang tidak jelas, tidak diketahui dan tidak pasti antara salah satu pihak, baik tentang barang maupun tentang harga yang akan diperjualbelikan atau ditransaksikan. ${ }^{33}$

Jadi bisnis atau transaksi yang terjadi antara dua pihak yang sifatnya terdapat unsur gharar adalah merupakan jual beli yang tidak memenuhi perjanjian dan tidak dapat dipercaya, tidak diketahui harganya, tidak diketahui secara jelas barangnya, dalam kondisi berbahaya keselamatan barangnya saat waktu dan akan diperolehnya dan kemungkinan bisa hilang atau tidak ada karena tidak jelas keberadaannya. Hal ini mungkin terjadi sebagai sebuah bentuk kejahatan dan penipuan, atau memperoleh keuntungan dengan cara yang tidak dibenarkan atau risiko yang menuju ketidakpastian di dalam suatu transaksi bisnis atau sejenisnya. Dengan demikian, praktik gharar ini tidak diperbolehkan, salah satu yang menjadi tujuannya adalah untuk menutup pintu munculnya permusuhan dan percekcokan yang disebabkan oleh perbuatan salah satu atau kedua belah pihak yang melakukan transaksi bisnis atau perekonomian seperti jual beli.

\section{Kesimpulan}

Berdasarkan penelitian terhadap matan hadis tentang larangan jual beli gharar, hadis yang diriwayatkan oleh ulama hadis berkualiatas sahịh, karena tidak bertentangan dengan al-Qur'an dan dalil-dalil lain yang sahịh. Penelitian terhadap matannya juga tidak ada bertentangan dengan Al-Qur'an, Sunnah Rasulullah saw dan kaedah Syariah Islam yang universal bahkan semakin mendukung terhadap doktrin yang ada yaitu melaksanakan jual beli dengan mengedepankan sifat jujur dan amanah. Oleh sebab itu, matan ini dapat dijadikan sebagai hujjah dan dalil bagi landasan hukum yang akan dibuat. Penilaian sanadnya juga masuk dalam kategori sahịh karena ittiṣāl sanad dan para rijalul hadisnya mendapatkan penilain dari banyak ulama dalam derajat siqah. Karena itu hadis-hadis yang diteliti dalam tulisan ini dapat dijadikan hujjah di dalam menetapkan hukum mengenai jual beli gharar yang terlarang.

${ }^{33}$ Ibid., 65-66. 
158 | AL QUDS : Jurnal Studi Alquran dan Hadis vol. 5, no 1, 2021

\section{Bibliografi}

Adly, Muhammad Amar dan Heri Firmansyah. "Hadis-Hadis tentang Riba dan Implementasinya dalam Sistem Perbankan”, Al Quds, Jurnal Studi Alquran dan Hadis, Volume 4, Nomor 2, 2020. DOI 10.29240/alquds.v4i2.1515.

al-'Asqalāniy, Ibnu Hajar. Taqrīb at-Tahżīb (Beirut: Dār al-Fikr, 1995), jild 2.

Ali, Atabik. 1998. Kamus Al-Ashri, Yogyakarta: Multi Karya Grafika.

Az-Zuhaili, Wahbah. al-Fiqh al-Islamiy wa Adillatubu, Terj. Abdul Hayyie AlKattani, Jilid 5,. Jakarta: Gema Insani, 2011.

Hosen, Nadratuzzaman. "Analisis Bentuk Gharar Dalam Transaksi Ekonomi” Jurnal UIN Syarif Hidayatullah. Al-Iqtishad, Jakarta: 2009.

Imām Abū Daud dalam Sunannya, Kitab Al-Buyu', Bab Fi Bai' al-Gharar, hadits no 2932.

Imām Ibnu Mājah. Sunan Ibnu Mājah. Riyaḍ: Maktabah Ma’arif, 1979.

Imām Nasā’i. Sunan an-Nasāì. Beirut: Daarul Fikri, 1989.

Karim, Adiwarman A. Bank Islam Analisis Fiqih danKenangan, Jakarta: RajaGrafindo.2013.

Karim, Adiwarman.Bank Islam: Analisis Figh dan Keuangan. Jakarta: Raja Grafido Persada, 2004.

Muslim, Imām. Șaḥịh Al-Muslim. Kairo: al-Maktabah al-Mișriyah, 1986.

Qal'aji , Muhammad. T.th. Mu'jam Lugah al-Fuqaha', Maktabah Syamilah.

Rahman, Muh. Fudhail. "Hakekat dan Batasan-Batasan Gharar dalam Transaksi Maliyab” Jurnal UIN Syarif Hidayatullah. Salam, Jakarta: 2018.

Santosa, Purbayu Budi dan Aris Anwaril Muttaqin. "Larangan Jual Beli Gharar dalam Musnad Ahmad bin Hanbal" Jurnal Universitas Diponegoro. Equilibrium, Semarang: 2015.

Tirmiżi, Imām. Jàmi' at-Tirmiẓ̌i. Kairo : Majmu al-Buhus al-Islamiyyah, 1969.

Warde, Ibrahim. Islamic Finance, terj. Andriyadi Ramli, Yogyakarta: Pustaka Pelajar, 2009. 